Article

\title{
Analysis of ABC Transporter Gene Expression in Atherosclerosis
}

\author{
Stanislav Kotlyarov $1, *$ (D) and Anna Kotlyarova ${ }^{2}$ (D) \\ 1 Department of Nursing, Ryazan State Medical University, 390026 Ryazan, Russia \\ 2 Department of Pharmacology and Pharmacy, Ryazan State Medical University, 390026 Ryazan, Russia; \\ kaa.rz@yandex.ru \\ * Correspondence: SKMR1@yandex.ru
}

check for updates

Citation: Kotlyarov, S.; Kotlyarova, A. Analysis of ABC Transporter Gene Expression in Atherosclerosis.

Cardiogenetics 2021, 11, 204-218. https://doi.org/10.3390/ cardiogenetics11040021

Received: 27 September 2021 Accepted: 1 November 2021 Published: 4 November 2021

Publisher's Note: MDPI stays neutral with regard to jurisdictional claims in published maps and institutional affiliations.

Copyright: (c) 2021 by the authors. Licensee MDPI, Basel, Switzerland. This article is an open access article distributed under the terms and conditions of the Creative Commons Attribution (CC BY) license (https:// creativecommons.org/licenses/by/ $4.0 /)$.

\begin{abstract}
A B C$ transporters are a large family of membrane proteins that transport chemically diverse substrates across the cell membrane. Disruption of transport mechanisms mediated by ABC transporters causes the development of various diseases, including atherosclerosis. Methods: A bioinformatic analysis of a dataset from Gene Expression Omnibus (GEO) was performed. A GEO dataset containing data on gene expression levels in samples of atherosclerotic lesions and control arteries without atherosclerotic lesions from carotid, femoral, and infrapopliteal arteries was used for analysis. To evaluate differentially expressed genes, a bioinformatic analysis was performed in comparison groups using the limma package in R (v. 4.0.2) and the GEO2R and Phantasus tools (v. 1.11.0). Results: The obtained data indicate the differential expression of many ABC transporters belonging to different subfamilies. The differential expressions of $\mathrm{ABC}$ transporter genes involved in lipid transport, mechanisms of multidrug resistance, and mechanisms of ion exchange are shown. Differences in the expression of transporters in tissue samples from different arteries are established. Conclusions: The expression of ABC transporter genes demonstrates differences in atherosclerotic samples and normal arteries, which may indicate the involvement of transporters in the pathogenesis of atherosclerosis.
\end{abstract}

Keywords: ABC transporters; atherosclerosis; gene expression; bioinformatic analysis

\section{Introduction}

Atherosclerosis is an important problem for modern mankind [1]. Its medical and social importance is steadily increasing. High levels of prevalence, disability, and mortality from diseases associated with atherosclerosis carry a heavy economic burden for both patients and their families as well as for public health systems [2].

Studies of the mechanisms of atherosclerosis development are particularly relevant, since early detection and early modification of disturbed processes can be an effective tool for preventing its complications. The results of numerous studies have improved our understanding of the pathogenesis of atherosclerosis. Disruption of cellular transport processes mediated by $\mathrm{ABC}$ transporters is known to contribute significantly to the development and progression of atherosclerosis at different stages [3].

ATP-binding cassette (ABC) transporters are a large family of proteins that are involved in the movement of a wide range of substrates across cell membranes [4]. In humans, $48 \mathrm{ABC}$ transporter proteins are known, which are divided into 7 subfamilies based on structural characteristics: ABCA-ABCG [5]. Currently, the role of several representatives of $\mathrm{ABC}$ transporters in the pathogenesis of atherosclerosis is well described [6]. The roles of the ABCA and ABCG subfamilies are best known due to the involvement of their members in lipid transport, disorders of which are an important part of the pathogenesis of atherosclerosis [4,7]. The significance of lipid metabolism disorders in the development of atherosclerosis is now sufficiently understood and supported by the results of numerous studies. Lipid accumulation in the vascular wall is considered to be one of the key stages 
of atherogenesis. Macrophages play an active role in this process, which is associated with their involvement in the uptake of modified lipoproteins in the arterial wall, the production of inflammatory mediators, and the secretion of metalloproteinases that contribute to plaque instability. Disruption of cholesterol homeostasis in macrophages and the accumulation of its esters in lipid droplets lead to the development of the so-called "foam cell" phenotype. At the same time, the reverse transport of cholesterol-its removal from the cells-provides protection of the arterial wall from unwanted lipid deposition. This important atheroprotective function is provided to a greater extent by ABCA1 and ABCG1 transporters. Other members of these subfamilies are also thought to be involved in providing lipid transport processes, but the biological role of many of them is currently unclear. It should be noted that cellular lipid transport can regulate many essential cellular functions. The lipid composition of plasma membranes is known to be complex, and its changes have a significant impact on both the biophysical properties of the membrane and the function of membrane proteins, including the assembly and function of inflammationrelated signaling pathways. All the mechanisms that link inflammation to the development and progression of atherosclerosis are still largely unknown, but the role of cross-linking inflammation with impaired lipid metabolism and the role of $A B C$ transporters in these processes are of great clinical interest.

While members of the $\mathrm{ABCB}$ and $\mathrm{ABCC}$ subfamilies are well known for their role in the development of multidrug resistance, there is increasing evidence of their involvement in the pathogenesis of other diseases, including atherosclerosis.

This multifaceted role also involves lipid transport, the functioning of ion channels, and the export of exogenous substances, which may be important in the pathogenesis of atherosclerosis.

It should be noted that the biological functions of many $A B C$ transporters are still the subject of study. In this regard, the study of their role in the pathogenesis of atherosclerosis may expand our understanding of atherogenesis.

Thus, the relevance of the problem of atherosclerosis and the need for a better understanding of its pathogenesis, including the mechanisms that are associated with the disruption of transport processes in cells, determined the purpose of the present study, which is to analyze the gene expression patterns of human $A B C$ transporters in atherosclerosis using bioinformatics analysis methods.

\section{Materials and Methods}

\subsection{Data Collection}

For the analysis, data from the publicly available set GSE100927, obtained from the Gene Expression Omnibus (GEO), National Center for Biotechnological Information (NCBI), were used. The GSE100927 set contained data on gene expression in atherosclerotic lesions and control arteries without atherosclerotic lesions from the carotid, femoral, and infra-popliteal arteries from patients undergoing carotid, femoral, or infrapopliteal endarterectomy [8]. The data were obtained using the GPL17077 Agilent-039494 SurePrint G3 Human GE v2 8x60K Microchip 039381 (Probe Name version) platform. Data normalization was carried out using locally weighted scattered plot smoother analysis (LOWESS).

\subsection{Data Extraction}

The following information was extracted for the dataset: the platform, the number of samples obtained from patients with atherosclerosis and healthy individuals, the location in the vascular bed from which the samples were obtained (carotid, femoral, and infrapopliteal arteries), and pre-processed gene expression data. To analyze the data on gene expression, comparison groups were formed: samples obtained from patients with atherosclerosis of various localizations and a control group of samples from healthy individuals.

The set included available data on gene expression in 29 samples of atherosclerotic lesions of the carotid arteries, 26 samples of atherosclerotic lesions of the femoral, and 14 samples of atherosclerotic lesions of the infrapopliteal arteries, as well as samples 
from control arteries without atherosclerotic lesions from 12 carotid, 12 femoral, and 11 infrapopliteal arteries.

\subsection{Differential Expression Analysis}

The analysis of differential gene expression in the comparison groups was carried out using GEO2R, Phantasus (v. 1.11.0), and the limma package in R (v. 4.0.2) $[9,10]$. Data on the differential expression of genes in the comparison groups for each set, including $p$ value, $\log \mathrm{FC}$, were obtained. The statistical significance level for multiple comparisons was corrected using the Benjamini-Hochberg algorithm (FDR-false discovery rate; adj. P.Value). All $p$ values satisfying the condition $<0.05$ at FDR $\leq 5 \%$ were considered statistically significant. Visualization of gene expression levels in comparison groups is presented as box diagrams, which demonstrate the minimum value (the lower part of the vertical line), the first-third quartile (box), the median (the horizontal line inside the box), and the maximum value (the upper part of the vertical line) of the data distribution.

\section{Results}

The conducted bioinformatic analysis showed differences in the expression of $\mathrm{ABC}$ transporter genes in each subfamily (Tables 1 and 2).

Table 1. The first 10 upregulated $A B C$ genes, ranked by $p$ values adjusted using the algorithm of Benjamini-Hochberg (adj. P. Val).

\begin{tabular}{|c|c|c|c|c|}
\hline $\begin{array}{c}\text { Gene } \\
\text { adj. P. Value } \\
\text { LogFC }\end{array}$ & Carotid Artery & Femoral Artery & Infrapopliteal Artery & $\begin{array}{l}\text { All Control/ } \\
\text { All Atherosclerosis }\end{array}$ \\
\hline gene & ABCC5 & ABCC5 & ABCA7 & ABCC5 \\
\hline adj. P. Value & $1.59 \times 10^{-11}$ & $1.98 \times 10^{-9}$ & $1.44 \times 10^{-6}$ & $2.48 \times 10^{-21}$ \\
\hline $\log \mathrm{FC}$ & 1.1592 & 1.1792 & 0.8770 & 1.1935 \\
\hline gene & ABCC3 & ABCA7 & ABCC5 & ABCA7 \\
\hline adj. P.Value & $3.46 \times 10^{-9}$ & $4.71 \times 10^{-7}$ & $8.04 \times 10^{-6}$ & $1.26 \times 10^{-17}$ \\
\hline $\log \mathrm{FC}$ & 0.9778 & 1.135 & 1.0856 & 1.0271 \\
\hline gene & ABCC10 & ABCF3 & ABCC10 & ABCF3 \\
\hline adj. P.Value & $3.86 \times 10^{-9}$ & $8.87 \times 10^{-6}$ & $6.91 \times 10^{-4}$ & $5.97 \times 10^{-14}$ \\
\hline $\log F C$ & 0.42413 & 0.4166 & 0.3789 & 0.4086 \\
\hline gene & ABCB5 & ABCD4 & $\mathrm{ABCD} 4$ & ABCC10 \\
\hline adj. P.Value & $9.57 \times 10^{-9}$ & $3.83 \times 10^{-5}$ & 0.00215 & $1.44 \times 10^{-12}$ \\
\hline $\log \mathrm{FC}$ & 1.6144 & 0.4432 & 0.5238 & 0.3407 \\
\hline gene & ABCF3 & ABCB1 & ABCF3 & $\mathrm{ABCD} 4$ \\
\hline adj. P.Value & $2.08 \times 10^{-7}$ & $3.33 \times 10^{-4}$ & 0.00341 & $1.93 \times 10^{-10}$ \\
\hline $\log \mathrm{FC}$ & 0.3565 & 0.4041 & 0.4214 & 0.3901 \\
\hline gene & ABCC6 & ABCC3 & ABCB1 & ABCB1 \\
\hline adj. P.Value & $2.40 \times 10^{-7}$ & 0.00188 & 0.00596 & $2.74 \times 10^{-9}$ \\
\hline $\log \mathrm{FC}$ & 0.3966 & 0.6402 & 0.2614 & 0.2710 \\
\hline gene & ABCA7 & $\mathrm{ABCC} 10$ & ABCC9 & ABCC 3 \\
\hline adj. P.Value & $8.71 \times 10^{-7}$ & 0.00455 & 0.01277 & $3.70 \times 10^{-9}$ \\
\hline $\log \mathrm{FC}$ & 0.9644 & 0.2812 & 0.5452 & 0.8043 \\
\hline gene & ABCA1 & ABCB5 & ABCG4 & ABCB5 \\
\hline adj. P.Value & $3.28 \times 10^{-5}$ & 0.00596 & 0.02498 & $1.50 \times 10^{-7}$ \\
\hline $\log \mathrm{FC}$ & 0.8161 & 0.6618 & 0.1732 & 0.9613 \\
\hline gene & ABCB1 & ABCB4 & ABCB4 & ABCC6 \\
\hline adj. P.Value & $6.07 \times 10^{-5}$ & 0.01090 & 0.03594 & $5.94 \times 10^{-5}$ \\
\hline $\log \mathrm{FC}$ & 0.2798 & 0.2947 & 0.2996 & 0.2018 \\
\hline gene & ABCD4 & ABCA5 & $\mathrm{ABCA} 2$ & ABCG4 \\
\hline adj. P.Value & $1.30 \times 10^{-4}$ & 0.03991 & 0.04503 & $1.19 \times 10^{-4}$ \\
\hline $\log \mathrm{FC}$ & 0.2161 & 0.2292 & 0.1712 & 0.2461 \\
\hline
\end{tabular}


Table 2. The first downregulated ABC genes, ranked by $p$ values adjusted using the algorithm of Benjamini-Hochberg (adj. P. Val).

\begin{tabular}{|c|c|c|c|c|}
\hline $\begin{array}{c}\text { Gene } \\
\text { adj. P.Value } \\
\text { LogFC }\end{array}$ & Carotid Artery & Femoral Artery & Infrapopliteal Artery & $\begin{array}{l}\text { All Control/ } \\
\text { All Atherosclerosis }\end{array}$ \\
\hline gene & ABCA8 & ABCD3 & ABCA8 & ABCA8 \\
\hline adj. P.Value & $1.67 \times 10^{-14}$ & 0.00106 & 0.00220 & $6.86 \times 10^{-17}$ \\
\hline LogFC & -1.8533 & -0.3349 & -1.067 & -1.3643 \\
\hline gene & ABCC9 & ABCA8 & ABCD1 & ABCD3 \\
\hline adj. P.Value & $2.20 \times 10^{-12}$ & 0.00124 & 0.02662 & $2.10 \times 10^{-7}$ \\
\hline $\log F C$ & -0.7550 & -0.9879 & -0.1222 & -0.2309 \\
\hline gene & $\mathrm{ABCC} 8$ & ABCF2 & & ABCF2 \\
\hline adj. P.Value & $6.57 \times 10^{-6}$ & 0.00212 & - & $2.00 \times 10^{-5}$ \\
\hline LogFC & -0.6352 & -0.2322 & & -0.2194 \\
\hline gene & ABCA10 & ABCE1 & & ABCC8 \\
\hline adj. P.Value & $2.20 \times 10^{-4}$ & 0.01666 & - & $1.33 \times 10^{-4}$ \\
\hline LogFC & -0.2184 & -0.2573 & & -0.4701 \\
\hline gene & ABCD3 & & & ABCA10 \\
\hline adj. P.Value & $2.39 \times 10^{-4}$ & - & - & 0.00125 \\
\hline $\log F C$ & -0.2705 & & & -0.1215 \\
\hline gene & ABCA9 & & & ABCA6 \\
\hline adj. P.Value & 0.00239 & - & - & 0.00302 \\
\hline $\log F C$ & -0.2275 & & & -0.3863 \\
\hline gene & ABCF2 & & & ABCC 9 \\
\hline adj. P.Value & 0.00842 & - & - & 0.00321 \\
\hline LogFC & -0.2754 & & & -0.6535 \\
\hline gene & $\mathrm{ABCC} 2$ & & & $\mathrm{ABCC} 2$ \\
\hline adj. P.Value & 0.017797 & - & - & 0.0094999 \\
\hline LogFC & -0.222 & & & -0.18827 \\
\hline gene & $\mathrm{ABCC} 1$ & & & ABCE1 \\
\hline adj. P.Value & 0.034844 & - & - & 0.013257 \\
\hline LogFC & -0.18642 & & & -0.11818 \\
\hline
\end{tabular}

In the ABCA subfamily, the most differentially expressed gene with upregulation in atherosclerotic samples is ABCA7 (Figure 1). The ABCA7 transporter is extensively involved in lipid transport, performing phospholipid translocation from the cytoplasm to the extracellular sheet of the plasma membrane. It also transports phosphatidylserine and cholesterol and plays a role in macrophage-mediated phagocytosis. ABCA7 demonstrates $49 \%$ amino acid sequence similarity with another member of the subfamily, ABCA1, whose differential expression was detected in datasets from the carotid artery. At the same time, ABCA8, which is also involved in lipid transport by exporting cholesterol, was found to be downregulated. ABCA10, which may play a role in lipid homeostasis and lipid transport in macrophages, was also shown to be downregulated. ABCA10 demonstrates high amino acid sequence homology with ABCA6, ABCA8, and ABCA9, known members of the ABCA6-like transporters subgroup. At the same time, ABCA6 itself also showed reduced expression in atherosclerosis. However, its function is currently largely unknown.

Among the members of the ABCB subfamily, the ABCB1 transporter gene, a key participant in the mechanism of multidrug resistance due to its ability to efflux xenobiotics, was found to be upregulated in atherosclerotic samples (Figure 2). ABCB1 is well known to clinicians and researchers for its role in the pharmacokinetics of many drugs with different chemical structures. Another representative, ABCB5, also responsible for reducing drug accumulation in cells and associated with multidrug resistance, also demonstrated upregulation in atherosclerotic samples. 

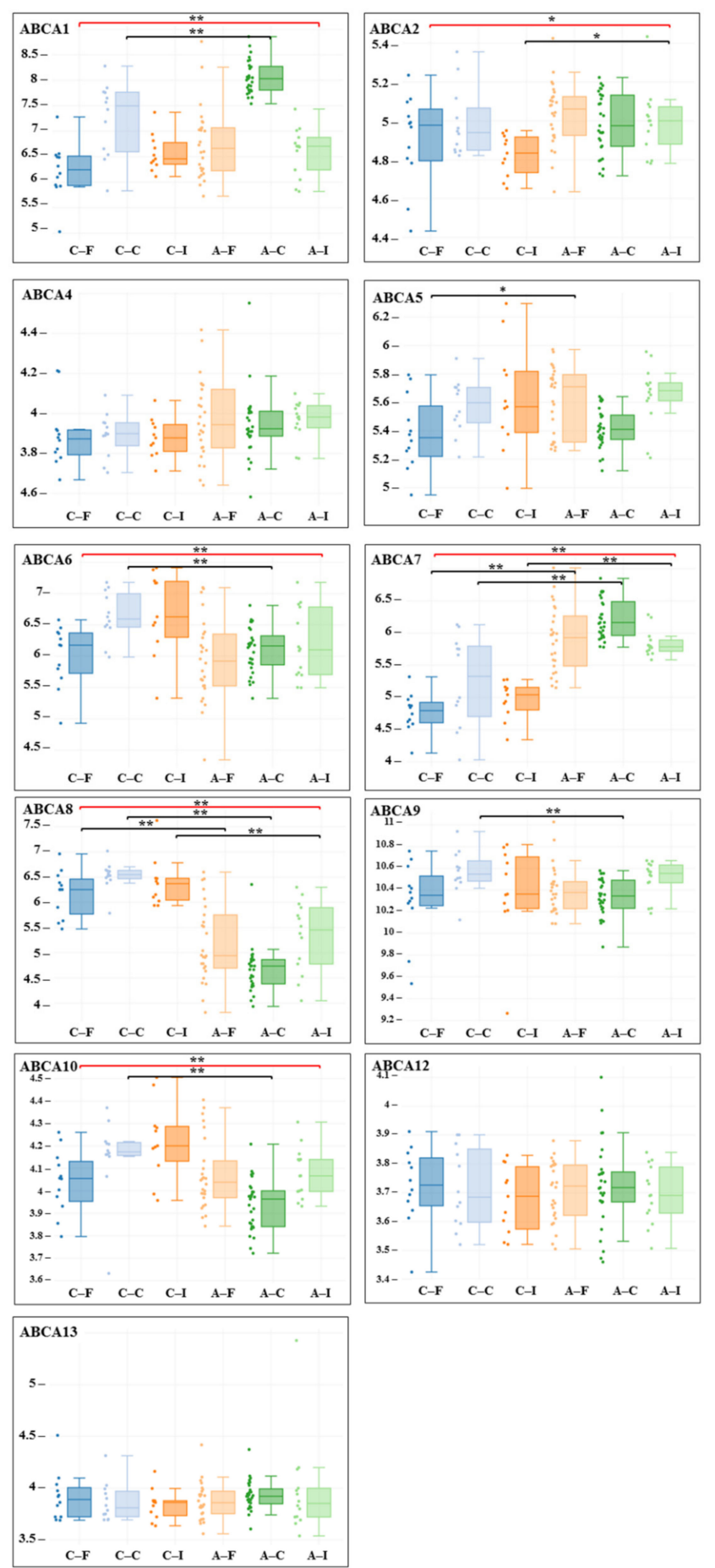

Figure 1. Gene expression patterns of the ABCA subfamily in the comparison groups: atheroscleroticfemoral artery (A-F); atherosclerotic - carotid artery (A-C); atherosclerotic-infrapopliteal artery (A-I); control—femoral artery $(\mathrm{C}-\mathrm{F})$; control—carotid artery $(\mathrm{C}-\mathrm{C})$; control—infrapopliteal artery $(\mathrm{C}-\mathrm{I})$. The red line shows the differences in gene expression in the group between all sets with atherosclerosis and all control sets. The data distribution is visualized in the form of box diagrams. Statistically significant differences ( $p$ values adjusted using the algorithm of Benjamini-Hochberg (adj. P. Val)) shown with asterisks: ${ }^{*} p<0.05,{ }^{* *} p<0.001$. 

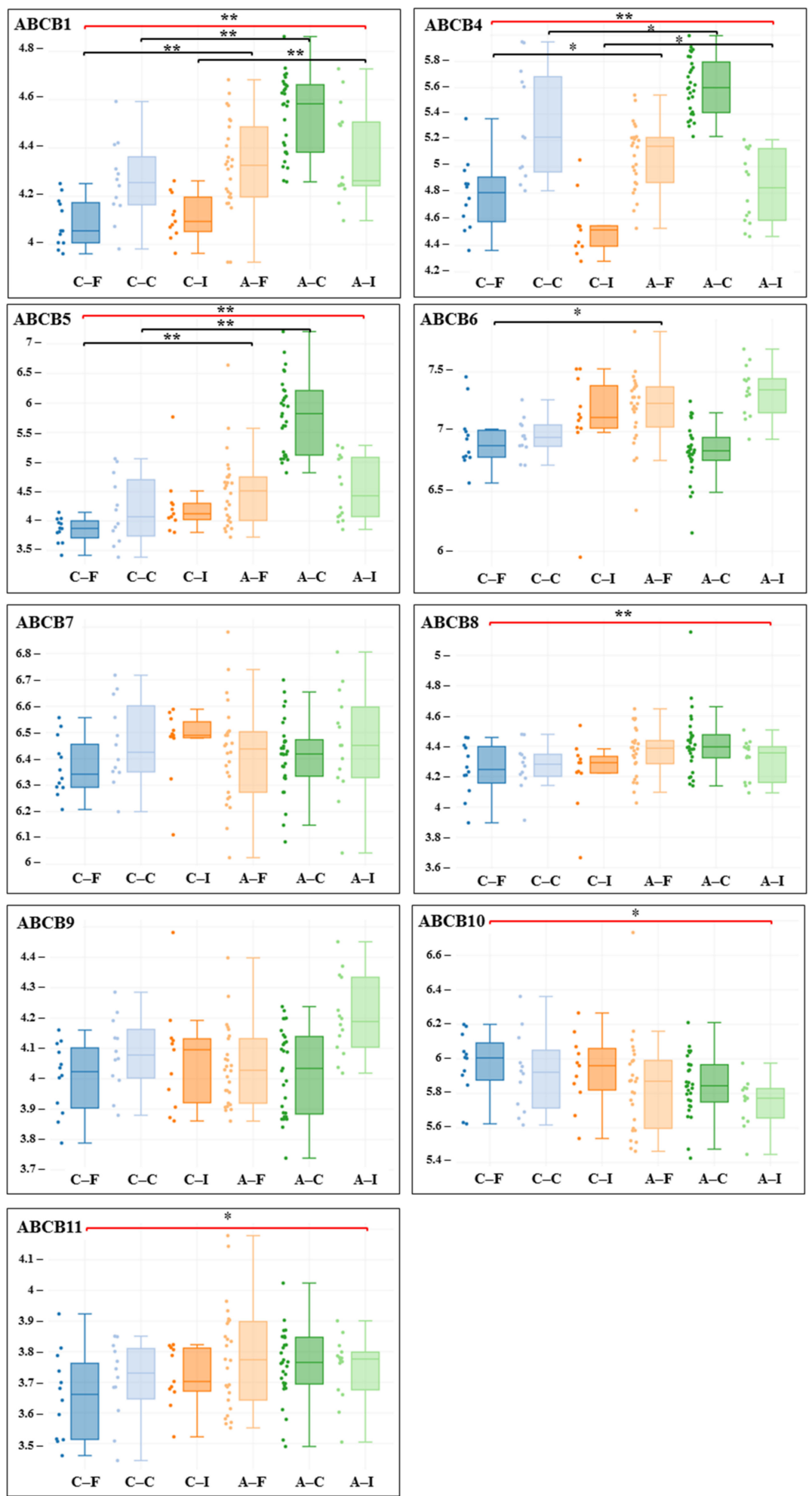

Figure 2. Gene expression patterns of the $\mathrm{ABCB}$ subfamily in the comparison groups: atheroscleroticfemoral artery (A-F); atherosclerotic-carotid artery (A-C); atherosclerotic-infra-popliteal artery (A-I); control-femoral artery $(\mathrm{C}-\mathrm{F})$; control—carotid artery $(\mathrm{C}-\mathrm{C})$; control—infra-popliteal artery $(\mathrm{C}-\mathrm{I})$. The red line shows the differences in gene expression in the group between all sets with atherosclerosis and all control sets. The data distribution is visualized in the form of box diagrams. Statistically significant differences ( $p$ values adjusted using the algorithm of Benjamini-Hochberg (adj. P. Val)) shown with asterisks: ${ }^{*} p<0.05,{ }^{* *} p<0.001$. 
In the $A B C C$ subfamily, increased expression of the $A B C C 5, A B C C 3$, and $A B C C 6$ genes was found in atherosclerotic samples (Figure 3). The ABCC5 transporter acts as a multi-specific organic anion pump that can transport nucleotide analogues. ABCC10, which is known for its role in the active release of physiological compounds such as leukotriene C4 (LTC4), as well as xenobiotics from cells, also showed increased expression. In this regard, this transporter also mediates multidrug resistance. ABCC 3 provides active transport across cell membranes of various substrates, including many drugs and toxic and endogenous compounds, such as LTC4. ABCC6 actively exports xenobiotics and physiological compounds from cells; for example, it mediates the transport of glutathione conjugates, such as LTC4.

At the same time, the $\mathrm{ABCC} 8, \mathrm{ABCC}$, and $\mathrm{ABCC} 2$ genes showed reduced differential expression. $\mathrm{ABCC} 8$ and $\mathrm{ABCC} 9$ are subunits of the ATP-sensitive potassium channel, and ABCC2 provides active transport across cell membranes of various substrates, including many drugs and toxic and endogenous compounds. The transporter is considered part of the mechanism of multidrug resistance.

Among members of the ABCG subfamily, an increased regulation was found in the ABCG4 gene (Figure 4). The ABCG4 transporter may be involved in macrophage lipid homeostasis. Among members of the ABCD subfamily, increased expression was found in $\mathrm{ABCD} 4$ and $\mathrm{ABCD} 1$ (carotid artery), while decreased expression was observed in $\mathrm{ABCD} 3$ and $\mathrm{ABCD} 1$ (infra-popliteal artery) (Figure 4). ABCD1 and ABCD3 participate in cellular lipid metabolism by importing fatty acyl-Koa (coenzyme A) into peroxisomes [11-13]. Moreover, ABCD3 moves branched, unsaturated, long-chain dicarboxylic acids [13].

Among members of the $\mathrm{ABCE}$ subfamily, decreased expression was found in $\mathrm{ABCE} 1$ (Table 2). There is currently no conclusive evidence that $A B C E 1$ is involved in any membrane transport functions. The ABCE1 protein, also known as the RNase L inhibitor (RLI), is a type of endoribonuclease Rnase $\mathrm{L}$ inhibitor that is involved in many biological processes, including the response to viral infection, cell proliferation, and evasion of apoptosis [14-17]. In addition, RNase L also plays an important role in protein translation [17-19] and multidrug resistance, and it is an important regulator of adipogenesis [20]. The functions of the $\mathrm{ABCF}$ members that have shown differential expression in atherogenesis are not known (Tables 1 and 2). The gene products of members of the ABCF subfamily do not have a transmembrane domain and are not involved in membrane transport functions. 


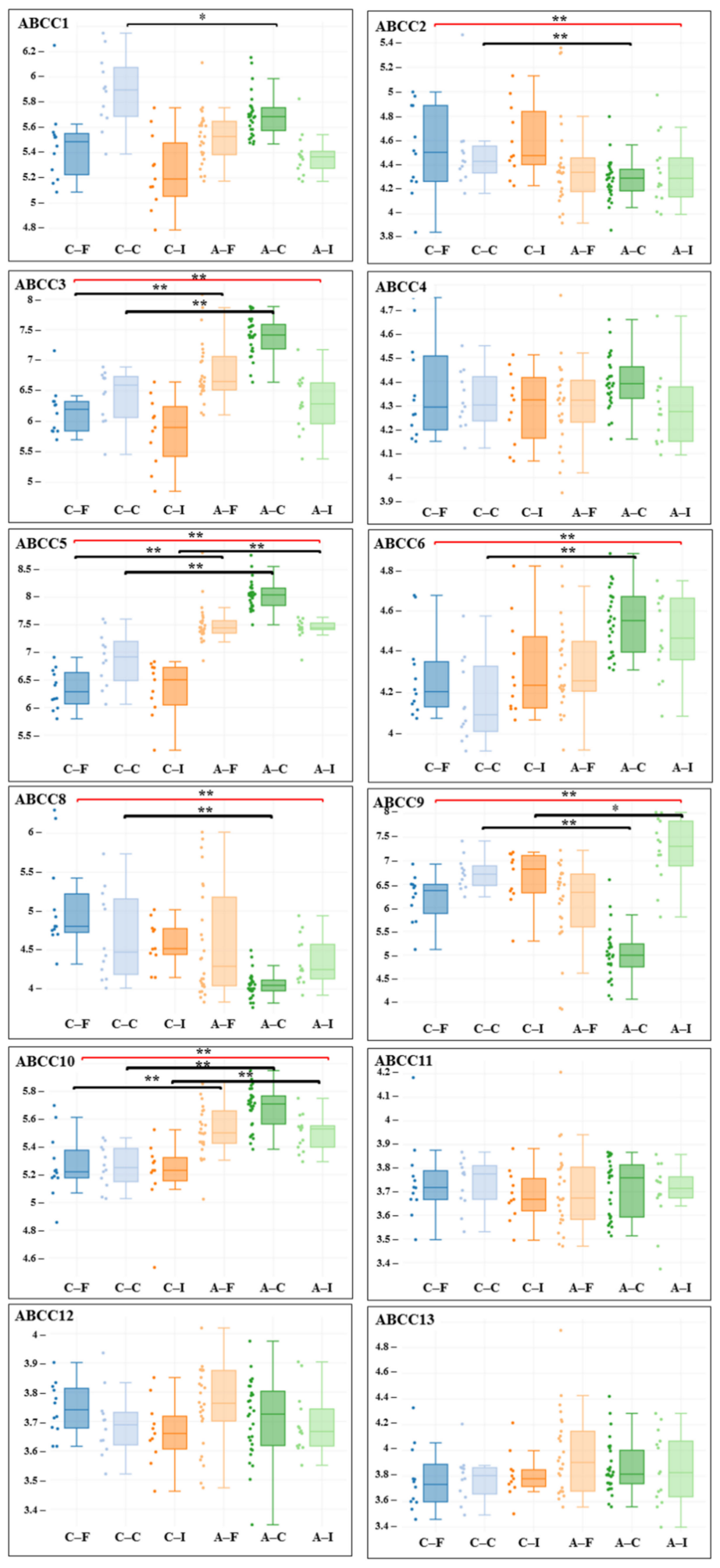

Figure 3. Gene expression patterns of the ABCC subfamily in the comparison groups: atheroscleroticfemoral artery (A-F); atherosclerotic - carotid artery (A-C); atherosclerotic-infra-popliteal artery (A-I); control—femoral artery $(\mathrm{C}-\mathrm{F})$; control—carotid artery $(\mathrm{C}-\mathrm{C})$; control—infra-popliteal artery (C-I). The red line shows the differences in gene expression in the group between all sets with atherosclerosis and all control sets. The data distribution is visualized in the form of box diagrams. Statistically significant differences ( $p$ values adjusted using the algorithm of Benjamini- Hochberg (adj. P. Val)) shown with asterisks: ${ }^{*} p<0.05,{ }^{* *} p<0.001$. 

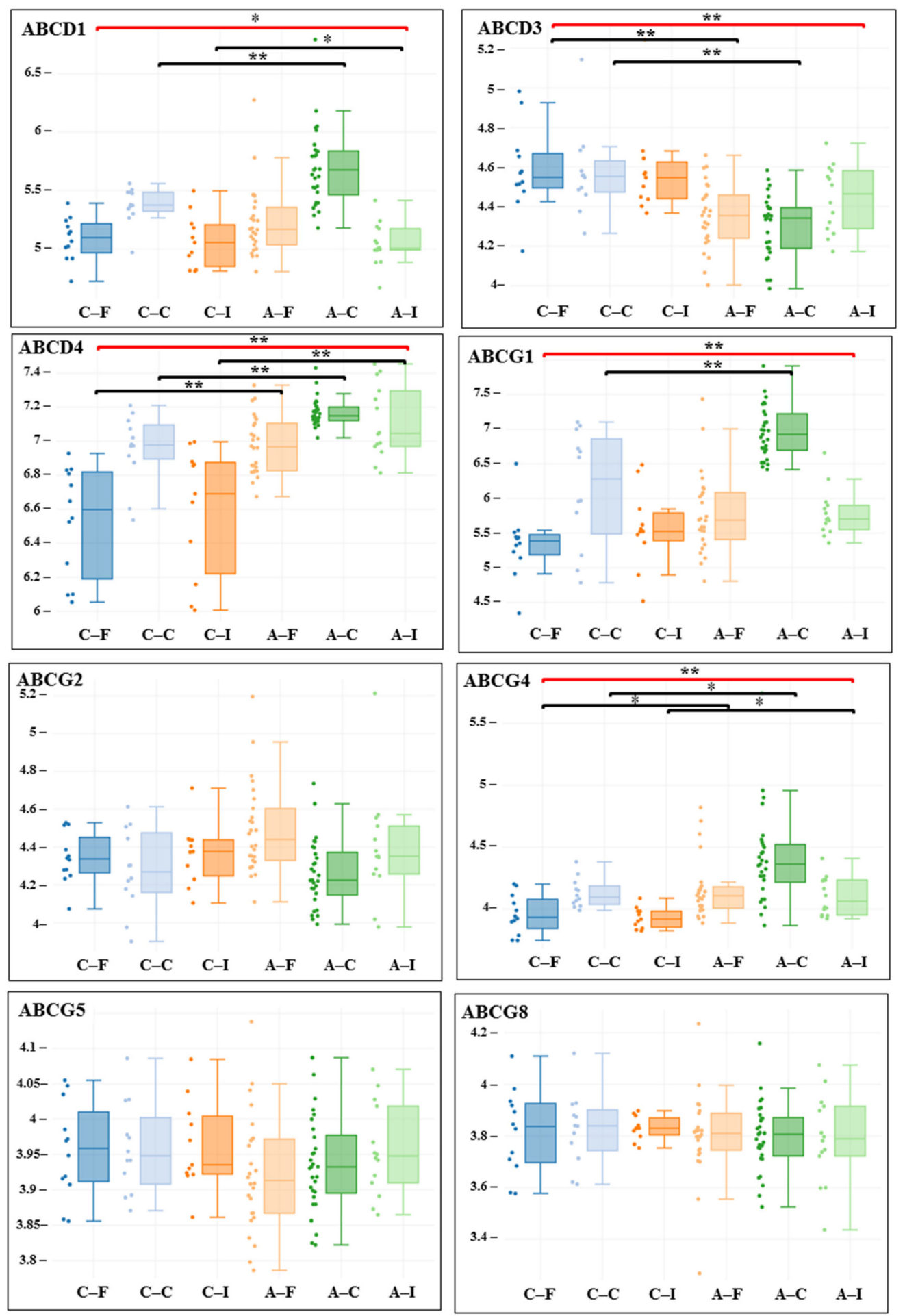

Figure 4. Gene expression patterns of the ABCD and ABCG subfamily in the comparison groups: atherosclerotic - femoral artery (A-F); atherosclerotic - carotid artery (A-C); atherosclerotic-infrapopliteal artery (A-I); control—femoral artery $(\mathrm{C}-\mathrm{F})$; control—carotid artery $(\mathrm{C}-\mathrm{C})$; control—infrapopliteal artery $(\mathrm{C}-\mathrm{I})$. The red line shows the differences in gene expression in the group between all sets with atherosclerosis and all control sets. The data distribution is visualized in the form of box diagrams. Statistically significant differences ( $p$ values adjusted using the algorithm of BenjaminiHochberg (adj. P. Val)) shown with asterisks: ${ }^{*} p<0.05,{ }^{* *} p<0.001$. 


\section{Discussion}

We performed bioinformatic analysis of $\mathrm{ABC}$ transporter gene expression in atherosclerotic samples and control samples without atherosclerotic lesions from carotid, femoral, and infrapopliteal arteries from patients undergoing carotid, femoral, or infrapopliteal endarterectomy from the GEO dataset. Using online analysis tools, we generated comparison groups: atherosclerotic samples and control samples. Our study included an analysis of the differential expression of $A B C$ transporter genes in each of the groups (from the carotid, femoral, and infra-popliteal arteries) and in general for atherosclerotic and control samples. Statistically significant differences in gene expression levels were taken into account, which were corrected using the Benjamini-Hochberg algorithm.

The analysis showed the presence of differentially expressed genes of several ABC transporters, which may indicate their involvement in cellular transport disorders in the pathogenesis of atherosclerosis. ABC transporters were chosen for analysis because they are one of the key protein families that enable the movement of many substrates across the cell membrane.

Given the current information on the pathogenesis of atherosclerosis, in which lipid metabolism disorders occur throughout its natural history, the data on the differential expression of $A B C$ transporters involved in lipid transport seem interesting. It is believed that about 20 members of the large family of $A B C$ transporters, which in humans includes 48 members, are involved in ensuring lipid homeostasis of cells by removing lipids from the cell or transporting them inside the cell and in its plasma membrane [11].

Impairment of lipid homeostasis is one of the key links in the pathogenesis of atherosclerosis. These impairments occur at different levels and involve multiple crosslinkages with inflammation, mechanoreception, and endothelial cell mechanotransduction. Excessive lipid accumulation in macrophages and lipid deposition in the vascular wall are known links in the complex chain of processes associated with the development of atherosclerosis.

Lipid transporters are found in all subfamilies of $A B C$ transporters, and the greatest role in the pathogenesis of atherosclerosis is known for members of the ABCA and ABCG subfamilies [11]. The data indicate that the highest differential expression in the ABCA subfamily in all compared groups was shown by ABCA7. ABCA7 is the closest homologue of $\mathrm{ABCA} 1$ and demonstrates some similar functions, carrying out lipid transport, primarily of phospholipids. ABCA1 ensures the export of cholesterol from macrophages. This function is considered one of the key ones in ensuring cholesterol homeostasis [21,22]. Decreased functional activity of ABCA1 leads to cellular accumulation of cholesterol with the formation of "foam cells". Thus, both transporters are characterized by atheroprotective effects, enabling the reverse transport of cholesterol from macrophages via its export with high-density lipoprotein (HDL). The findings that ABCA7 and ABCA1 expression was upregulated are interesting. Similar data were obtained in another study that found elevated levels of ABCA1 mRNA in atherosclerotic plaques, with higher levels of ABCA1 mRNA found in grade II and III plaques. These data allow ABCA1 mRNA levels to be considered as markers of plaque stability. The upregulation of ABCA1 mRNA may be associated with an increase in plaque oxysterol content [23]. Interestingly, ABCA1 protein levels in the study by Heang-Fang Liu et al. were markedly reduced in plaques compared with control tissues, reflecting a negative effect on cholesterol transport in atherosclerotic plaque [23]. These data indicate the need to take into account the expression data of the gene and transporter protein to assess its disorders in atherosclerosis.

In the ABCG subfamily, the ABCG4 gene showed the highest differential expression. It is known that ABCG4 demonstrates a high level of homology with the protein ABCG1, which is considered to be one of the key participants in the reverse transport of cholesterol from macrophages, preventing their transformation into "foam cells" [21]. Given this homologue, it is assumed that ABCG1 is also involved in the export of cholesterol to HDL $[6,24]$. However, the predominant localization of the ABCG4 transporter is not related to blood vessels. ABCG4 is found in bone marrow megakaryocyte progenitors and 
protects cells from sterol overload, and its role in the progression of atherosclerosis remains uncertain [6].

In the $A B C B$ subfamily, the $A B C B 1$ and $A B C B 5$ genes showed the most differential expression. The ABCB1 transporter (MDR1, multiple drug resistence 1) is well known for its role in the development of the mechanism of multidrug resistance. Other studies have already shown increased ABCB1 mRNA in atherosclerosis samples [21,25-27]. A possible role of the transporter in atherosclerotic lesions seems interesting [25]. These data allow us to reinforce the notion that the function of $\mathrm{ABCB} 1$ may be considered not only from the standpoint of its involvement in the export of xenobiotics and mechanisms of multidrug resistance but also in the transport of endogenous substances in some diseases. Higher levels of cholesterol esters and MDR1 mRNA and lower levels of caveolin-1 mRNA were found in smooth muscle cells from atherosclerotic lesions in arteries [25]. It is assumed that ABCB1 is involved in the intracellular accumulation of cholesterol esters detected in atherosclerotic lesions [26,27]. This is due to the role of ABCB1 in the transport of free cholesterol from the plasma membrane to the endoplasmic reticulum for its subsequent esterification by Acyl-CoA:cholesterol acyltransferase (ACAT) [27]. The upregulated expression of ABCB1 may be due to the fact that it is sensitive to activation by liver $X$ receptor (LXR) agonists and is also activated by differentiation from monocytes to macrophages $[21,28]$.

Increased expression of ABCB5 was also previously detected in atherosclerotic plaques in another study. The role of ABCB5 in atherogenesis is not clear, but it is known that the ABCB5 protein was detected in smooth muscle cells in normal samples and in large quantities in the necrotized plaque core [29].

ABCC6 is currently regarded as a key participant in ectopic calcification [30,31]. Although its role in atherogenesis is not clear, ABCC6 dysfunction increases the risk of vascular calcification and myocardial infarction [6,31-33]. Calcification is associated with atherosclerosis and coronary heart disease $[6,32,33]$. In addition, ABCC6 gene mutations are associated with generalized arterial calcification in infancy $[34,35]$.

ABCC8 (sulfonylurea receptor 1 (SUR1)) and ABCC9 (sulfonylurea receptor 2 (SUR2)) are the subunits of ATP-sensitive potassium channels $\mathrm{K}+$ channels [36,37]. Their role in the pathogenesis of atherosclerosis is not clear, but through the regulation of $\mathrm{K}+$ channels in vascular smooth muscle cells, they can participate in the regulation of vascular tone and blood pressure [6]. Sur $2-/-$ mice exhibited hypertension and coronary artery vasospasm accompanied by recurrent episodes of ST-segment elevation, during which decreased heart rate was recorded due to atrioventricular heart block and sudden cardiac death [38]. The data obtained on the downregulated expression of ABCC 8 and ABCC9 in atherosclerotic samples may indicate their involvement in atherogenesis, which requires further investigation.

ABCC1 (MRP1), ABCC2 (MRP2), ABCC3 (MRP3), ABCC4 (MRP4), ABCC5 (MRP5), ABCC6 (MRP6), and ABCC10 (MRP7) are members of the multidrug resistance protein (MRP) family that causes multidrug resistance [39]. Their function in the pathogenesis of atherosclerosis is not clear, but it should be considered that they carry out the outflow of many xenobiotics and endogenous substances [37]. There are also data on the direct involvement of members of $\mathrm{ABCC}$ transporters in atherogenesis, such as $\mathrm{ABCC} 1$, which is found in vascular smooth muscle cells involved in the process of atherosclerosis [40].

The relationship of $\mathrm{ABCC} 1, \mathrm{ABCC} 2, \mathrm{ABCC} 4, \mathrm{ABCC} 6$, and $\mathrm{ABCC} 10$ transporters that carry out LTC 4 transport with inflammation is interesting. Leukotrienes are a group of highly effective lipid mediators that are important participants in inflammation. In this regard, the transport activity of ABCC may be involved in inflammation. Their importance in atherogenesis can also be emphasized by their participation in the transport of glutathione, oxidized glutathione, and leukotriene C4 (LTC4) [40-42], potentially necessary for the regulation of reactive oxygen species production in vascular cells. It is suggested that the release of LTC4 under the action of ABCC1 from vascular smooth muscle cells may be important in the early stages of atherosclerotic lesion development. Later, macrophages are likely to be the main source of LTC4. Indeed, the modulation of ABCC1 expression in 
human aortic endothelial cells affects vascular function [40-42]. ABCC1 is also involved in the export of sphingosine-1-phosphate (S1P), a lipid mediator that is involved in inflammation, angiogenesis, apoptosis and macrophage function, and regulation of endothelial barrier integrity through modulation of the endothelial cytoskeleton [43-52]. The transporters belonging to this group showed a multidirectional pattern of differential expression. Moreover, ABCC10 showed the most significant increase in expression in atherosclerotic samples, whereas ABCC4 showed no difference, and ABCC1 showed differences only for carotid artery samples. These data suggest that the role of these members of the ABC transporters in atherogenesis needs to be better investigated.

The data obtained in the present study allow increased attention to several ABC transporters that have demonstrated differential expression and may potentially be involved in atherogenesis, or their differences may be related to the provision of impaired transport processes that are seen in atherosclerosis.

Directions for further research may be to assess not only the differential expression of $\mathrm{ABC}$ transporter genes but also the protein, given the available literature suggesting that these may differ. In this regard, evaluation of gene expression and protein analysis will improve the interpretation of the data.

Another important area for ABC transporter studies is the assessment of changes in protein expression and functional activity with age. There is evidence of age-related changes in ABC transporter gene expression, which may be of clinical significance. For example, in brain microvessels, the expression and functional activity of ABCB1 significantly decrease with age [53-57].

The expression level of the ABCA1 gene can also be correlated with ageing and is reduced by the DNA methylation process of ABCA1 [58-60]. Similar data correlating age and expression are available for other transporters, such as ABCA7 [61]. However, analysis of the correlation between ABCC3 expression and age found no significant change [62]. In addition, there may be differences in different organs. For example, there are no data in the literature on age-related changes and the effects of physiological aging on breast cancer resistance protein (BCRP/ABCG2) expression and/or function in endothelial cells, but a decrease in expression at the protein level has been described in liver during aging, whereas no significant differences were observed in the level of ABCG2 gene expression during aging [63].

These data are of potential interest from the perspective of the role of age-related changes in the expression and functional activity of $A B C$ transporters in the pathogenesis of atherosclerosis.

\section{Limitations of the Study}

It should be noted that this study has a number of limitations due to the fact that the dataset contains a small number of patients; there are no data on the stage of progression of atherosclerotic lesions; there is a lack of sufficient information on the intake of drugs by patients whose data are available for analysis that can affect lipid metabolism and ABC transporters.

An important limitation of the present study is that only ABC transporter gene expression data were evaluated, and protein-level expression data were not analyzed. Together, these data may significantly expand our understanding of the role of $\mathrm{ABC}$ transporters in the pathogenesis of atherosclerosis.

However, the data obtained in this study will help to better plan an experimental study to assess the differential expression of ABC transporters in atherosclerosis.

\section{Conclusions}

Thus, the bioinformatic analysis showed that atherosclerotic lesions are characterized by differential expression of $\mathrm{ABC}$ transporter genes. This can lead to disruption of transport processes for many groups of endogenous and exogenous substances, modulating the natural course of atherosclerosis and affecting treatment. Most of the ABC transporters 
differentially expressed in atherosclerosis have been shown to be related to lipid transport, ion channel function, and export of endogenous and exogenous substances, which are part of the mechanism of multidrug resistance. The obtained differences in the expression of $\mathrm{ABC}$ transporters in atherosclerotic specimens of different localization in the vascular bed may be related to both the peculiarities of atherosclerosis progression of different localization and the stage of atherosclerotic plaque development.

In this regard, further studies on the role of $A B C$ transporters in the pathogenesis of atherosclerosis, taking into account the data obtained in the present study, may be of clinical interest.

Author Contributions: Conceptualization, S.K.; methodology, S.K.; software, S.K.; validation, S.K. and A.K.; formal analysis, S.K. and A.K.; investigation, S.K.; resources, S.K.; data curation, S.K. and A.K.; writing—original draft preparation, S.K.; writing—review and editing, S.K. and A.K.; visualization, S.K.; supervision, S.K.; project administration, S.K. All authors have read and agreed to the published version of the manuscript.

Funding: This research received no external funding.

Institutional Review Board Statement: Not applicable.

Informed Consent Statement: Not applicable.

Data Availability Statement: The data presented in this study are available on request from the corresponding author.

Conflicts of Interest: The authors declare no conflict of interest.

\section{References}

1. Herrington, W.; Lacey, B.; Sherliker, P.; Armitage, J.; Lewington, S. Epidemiology of Atherosclerosis and the Potential to Reduce the Global Burden of Atherothrombotic Disease. Circ. Res. 2016, 118, 535-546. [CrossRef] [PubMed]

2. Song, P.; Fang, Z.; Wang, H.; Cai, Y.; Rahimi, K.; Zhu, Y.; Fowkes, F.G.R.; Fowkes, F.J.I; Rudan, I. Global and regional prevalence, burden, and risk factors for carotid atherosclerosis: A systematic review, meta-analysis, and modelling study. Lancet Glob. Health 2020, 8, e721-e729. [CrossRef]

3. Fitzgerald, M.L.; Mujawar, Z; Tamehiro, N. ABC transporters, atherosclerosis and inflammation. Atherosclerosis 2010, 211, 361-370. [CrossRef] [PubMed]

4. Vasiliou, V.; Vasiliou, K.; Nebert, D.W. Human ATP-binding cassette (ABC) transporter family. Hum. Genom. 2008, 3, $281-290$. [CrossRef]

5. Wilkens, S. Structure and mechanism of ABC transporters. F1000Prime Rep. 2015, 7, 14. [CrossRef]

6. Schumacher, T.; Benndorf, R.A. ABC Transport Proteins in Cardiovascular Disease—A Brief Summary. Molecules 2017, $22,589$. [CrossRef]

7. Tarling, E.J.; Vallim, T.Q.D.A.; Edwards, P.A. Role of ABC transporters in lipid transport and human disease. Trends Endocrinol. Metab. 2013, 24, 342-350. [CrossRef]

8. Steenman, M.; Espitia, O.; Maurel, B.; Guyomarch, B.; Heymann, M.-F.; Pistorius, M.-A.; Ory, B.; Heymann, D.; Houlgatte, R.; Gouëffic, Y.; et al. Identification of genomic differences among peripheral arterial beds in atherosclerotic and healthy arteries. Sci. Rep. 2018, 8, 3940. [CrossRef]

9. Zenkova, D.; Kamenev, V.; Sablina, R.; Artyomov, M.; Sergushichev, A. Phantasus: Visual and Interactive Gene Expression Analysis. Available online: https://ctlab.itmo.ru/phantasus/ (accessed on 27 September 2021).

10. Ritchie, M.E.; Phipson, B.; Wu, D.; Hu, Y.; Law, C.W.; Shi, W.; Smyth, G.K. limma powers differential expression analyses for RNA-sequencing and microarray studies. Nucleic Acids Res. 2015, 43, e47. [CrossRef]

11. Neumann, J.; Rose-Sperling, D.; Hellmich, U.A. Diverse relations between ABC transporters and lipids: An overview. Biochim. Biophys. Acta Biomembr. 2017, 1859, 605-618. [CrossRef]

12. Van Roermund, C.W.T.; Visser, W.F.; Ijlst, L.; van Cruchten, A.; Boek, M.; Kulik, W.; Waterham, H.R.; Wanders, R.J.A. The human peroxisomal $A B C$ half transporter ALDP functions as a homodimer and accepts acyl-CoA esters. FASEB J. 2008, 22, 4201-4208. [CrossRef]

13. Morita, M.; Imanaka, T. Peroxisomal ABC transporters: Structure, function and role in disease. Biochim. Biophys. Acta Mol. Basis Dis. 2012, 1822, 1387-1396. [CrossRef]

14. Bisbal, C.; Martinand, C.; Silhol, M.; Lebleu, B.; Salehzada, T. Cloning and Characterization of a RNase L Inhibitor. A new component of the interferon-regulated 2-5A pathway. J. Biol. Chem. 1995, 270, 13308-13317. [CrossRef]

15. Hassel, B.; Zhou, A.; Sotomayor, C.; Maran, A.; Silverman, R. A dominant negative mutant of 2-5A-dependent RNase suppresses antiproliferative and antiviral effects of interferon. EMBO J. 1993, 12, 3297-3304. [CrossRef] 
16. Le Roy, F.; Bisbal, C.; Silhol, M.; Martinand, C.; Lebleu, B.; Salehzada, T. The 2-5A/RNase L/RNase L Inhibitor (RNI) Pathway Regulates Mitochondrial mRNAs Stability in Interferon $\alpha$-treated H9 Cells. J. Biol. Chem. 2001, 276, 48473-48482. [CrossRef]

17. Tian, Y.; Tian, X.; Han, X.; Chen, Y.; Song, C.-Y.; Zhang, Y.-B.; Tian, D.-L. Expression of ATP binding cassette E1 enhances viability and invasiveness of lung adenocarcinoma cells in vitro. Mol. Med. Rep. 2016, 14, 1345-1350. [CrossRef]

18. Chen, Z.-Q.; Dong, J.; Ishimura, A.; Daar, I.; Hinnebusch, A.G.; Dean, M. The Essential Vertebrate ABCE1 Protein Interacts with Eukaryotic Initiation Factors. J. Biol. Chem. 2006, 281, 7452-7457. [CrossRef]

19. Pisareva, V.P.; Skabkin, M.A.; Hellen, C.U.T.; Pestova, T.V.; Pisarev, A.V. Dissociation by Pelota, Hbs1 and ABCE1 of mammalian vacant $80 \mathrm{~S}$ ribosomes and stalled elongation complexes. EMBO J. 2011, 30, 1804-1817. [CrossRef]

20. Fabre, O.; Salehzada, T.; Lambert, K.; Seok, Y.B.; Zhou, A.; Mercier, J.; Bisbal, C. RNase L controls terminal adipocyte differentiation, lipids storage and insulin sensitivity via CHOP10 mRNA regulation. Cell Death Differ. 2012, 19, 1470-1481. [CrossRef]

21. Pennings, M.; Meurs, I.; Ye, D.; Out, R.; Hoekstra, M.; Van Berkel, T.J.; Van Eck, M. Regulation of cholesterol homeostasis in macrophages and consequences for atherosclerotic lesion development. FEBS Lett. 2006, 580, 5588-5596. [CrossRef]

22. Kotlyarov, S. Participation of ABCA1 Transporter in Pathogenesis of Chronic Obstructive Pulmonary Disease. Int. J. Mol. Sci. 2021, 22, 3334. [CrossRef]

23. Liu, H.-F.; Cui, K.-F.; Wang, J.-P.; Zhang, M.; Guo, Y.-P.; Li, X.-Y.; Jiang, C. Significance of ABCA1 in human carotid atherosclerotic plaques. Exp. Ther. Med. 2012, 4, 297-302. [CrossRef]

24. Murphy, A.; Bijl, N.; Yvan-Charvet, L.; Welch, C.B.; Bhagwat, N.; Reheman, A.; Wang, Y.; A Shaw, J.; Levine, R.L.; Ni, H.; et al. Cholesterol efflux in megakaryocyte progenitors suppresses platelet production and thrombocytosis. Nat. Med. 2013, 19, 586-594. [CrossRef]

25. Batetta, B.; Mulas, M.; Petruzzo, P.; Putzolu, M.; Bonatesta, R.; Sanna, F.; Cappai, A.; Brotzu, G.; Dessì, S. Opposite pattern of MDR1 and caveolin-1 gene expression in human atherosclerotic lesions and proliferating human smooth muscle cells. Cell. Mol. Life Sci. 2001, 58, 1113-1120. [CrossRef]

26. Petruzzo, P.; Cappai, A.; Brotzu, G.; Batetta, B.; Putzolu, M.; Mulas, M.; Bonatesta, R.; Sanna, F.; Dessì, S. Lipid Metabolism and Molecular Changes in Normal andAtherosclerotic Vessels. Eur. J. Vasc. Endovasc. Surg. 2001, 22, 31-36. [CrossRef]

27. Batetta, B.; Dessì, S.; Putzolu, M.; Sanna, F.; Spano, O.; Mulas, M.F.; Petruzzo, P.; Cappai, A.; Brotzu, G. MDR1 Gene Expression in Normal and Atherosclerotic Human Arteries1. J. Vasc. Res. 1999, 36, 261-271. [CrossRef]

28. Saint-Pol, J.; Candela, P.; Boucau, M.-C.; Fenart, L.; Gosselet, F. Oxysterols decrease apical-to-basolateral transport of Aß peptides via an ABCB1-mediated process in an in vitro Blood-brain barrier model constituted of bovine brain capillary endothelial cells. Brain Res. 2013, 1517, 1-15. [CrossRef]

29. Wadén, K.; Lengquist, M.; Paulsson-Berne, G.; Hedin, U.; Roy, J.; Matic, L. Abstract 139: Correlation of Clinical Risk Scores for Stroke with Carotid Plaque Gene Expression Profiles in Atherosclerotic Patients. Arterioscler. Thromb. Vasc. Biol. 2019, 39 , A139. [CrossRef]

30. Favre, G.; Laurain, A.; Aranyi, T.; Szeri, F.; Fulop, K.; Le Saux, O.; Duranton, C.; Kauffenstein, G.; Martin, L.; Lefthériotis, G. The ABCC6 Transporter: A New Player in Biomineralization. Int. J. Mol. Sci. 2017, 18, 1941. [CrossRef]

31. Le Saux, O.; Martin, L.; Aherrahrou, Z.; Leftheriotis, G.; Váradi, A.; Brampton, C.N. The molecular and physiological roles of ABCC6: More than meets the eye. Front. Genet. 2012, 3, 289. [CrossRef]

32. Atzeni, F.; Sarzi-Puttini, P.; Bevilacqua, M. Calcium Deposition and Associated Chronic Diseases (Atherosclerosis, Diffuse Idiopathic Skeletal Hyperostosis, and Others). Rheum. Dis. Clin. N. Am. 2006, 32, 413-426. [CrossRef]

33. Trip, M.D.; Smulders, Y.M.; Wegman, J.J.; Hu, X.; Boer, J.M.; Brink, J.B.T.; Zwinderman, A.H.; Kastelein, J.J.; Feskens, E.J.; Bergen, A.A. Frequent mutation in the ABCC6 gene (R1141X) is associated with a strong increase in the prevalence of coronary artery disease. Circulation 2002, 106, 773-775. [CrossRef] [PubMed]

34. De Vilder, E.Y.G.; Hosen, M.J.; Vanakker, O.M. The ABCC6 Transporter as a Paradigm for Networking from an Orphan Disease to Complex Disorders. BioMed Res. Int. 2015, 2015, 1-18. [CrossRef] [PubMed]

35. Li, Q.; Brodsky, J.L.; Conlin, L.K.; Pawel, B.; Glatz, A.C.; Gafni, R.I.; Schurgers, L.; Uitto, J.; Hakonarson, H.; Deardorff, M.A.; et al. Mutations in the ABCC6 Gene as a Cause of Generalized Arterial Calcification of Infancy: Genotypic Overlap with Pseudoxanthoma Elasticum. J. Investig. Dermatol. 2014, 134, 658-665. [CrossRef]

36. Keppler, D. Multidrug resistance proteins (MRPs, ABCCs): Importance for pathophysiology and drug therapy. Handb. Exp. Pharmacol. 2011, 299-323. [CrossRef]

37. Sodani, K.; Patel, A.; Kathawala, R.J.; Chen, Z.-S. Multidrug resistance associated proteins in multidrug resistance. Chin. J. Cancer 2012, 31, 58-72. [CrossRef]

38. Chutkow, W.A.; Pu, J.; Wheeler, M.T.; Wada, T.; Makielski, J.C.; Burant, C.F.; McNally, E.M. Episodic coronary artery vasospasm and hypertension develop in the absence of Sur2 KATP channels. J. Clin. Investig. 2002, 110, 203-208. [CrossRef]

39. Tian, Q.; Zhang, J.; Chan, E.; Duan, W.; Zhou, S. Multidrug resistance proteins (MRPs) and implication in drug development. Drug Dev. Res. 2005, 64, 1-18. [CrossRef]

40. Wang, L.; Li, H.; Tang, Y.; Yao, P. Potential Mechanisms and Effects of Efferocytosis in Atherosclerosis. Front. Endocrinol. 2021, 11, 585285. [CrossRef]

41. Nofer, J.-R.; Herminghaus, G.; Brodde, M.; Morgenstern, E.; Rust, S.; Engel, T.; Seedorf, U.; Assmann, G.; Bluethmann, H.; Kehrel, B.E. Impaired Platelet Activation in Familial High Density Lipoprotein Deficiency (Tangier Disease). J. Biol. Chem. 2004, 279, 34032-34037. [CrossRef] 
42. Kotlyarov, S.; Kotlyarova, A. The Role of ABC Transporters in Lipid Metabolism and the Comorbid Course of Chronic Obstructive Pulmonary Disease and Atherosclerosis. Int. J. Mol. Sci. 2021, 22, 6711. [CrossRef]

43. Low, F.G.; Shabir, K.; Brown, J.E.; Bill, R.M.; Rothnie, A.J. Roles of ABCC1 and ABCC4 in Proliferation and Migration of Breast Cancer Cell Lines. Int. J. Mol. Sci. 2020, 21, 7664. [CrossRef]

44. Weigert, A.; Weis, N.; Brüne, B. Regulation of macrophage function by sphingosine-1-phosphate. Immunobiology 2009, 214, 748-760. [CrossRef]

45. Takabe, K.; Kim, R.H.; Allegood, J.C.; Mitra, P.; Ramachandran, S.; Nagahashi, M.; Harikumar, K.; Hait, N.C.; Milstien, S.; Spiegel, S. Estradiol Induces Export of Sphingosine 1-Phosphate from Breast Cancer Cells via ABCC1 and ABCG2. J. Biol. Chem. 2010, 285, 10477-10486. [CrossRef]

46. Yamada, A.; Nagahashi, M.; Aoyagi, T.; Huang, W.-C.; Lima, S.; Hait, N.C.; Maiti, A.; Kida, K.; Terracina, K.P.; Miyazaki, H.; et al. ABCC1-Exported Sphingosine-1-phosphate, Produced by Sphingosine Kinase 1, Shortens Survival of Mice and Patients with Breast Cancer. Mol. Cancer Res. 2018, 16, 1059-1070. [CrossRef]

47. Nagahashi, M.; Takabe, K.; Terracina, K.P.; Soma, D.; Hirose, Y.; Kobayashi, T.; Matsuda, Y.; Wakai, T. Sphingosine-1-Phosphate Transporters as Targets for Cancer Therapy. BioMed Res. Int. 2014, 2014, 1-7. [CrossRef]

48. Olivera, A.; Spiegel, S. Sphingosine kinase: A mediator of vital cellular functions. Prostaglandins Other Lipid Mediat. 2001, 64, 123-134. [CrossRef]

49. Pyne, S.; Pyne, N.J. Sphingosine 1-phosphate signalling and termination at lipid phosphate receptors. Biochim. Biophys. Acta Mol. Cell Biol. Lipids 2002, 1582, 121-131. [CrossRef]

50. Spiegel, S.; Milstien, S. Exogenous and intracellularly generated sphingosine 1-phosphate can regulate cellular processes by divergent pathways. Biochem. Soc. Trans. 2003, 31, 1216-1219. [CrossRef]

51. Spiegel, S.; Milstien, S. Sphingosine-1-phosphate: An enigmatic signalling lipid. Nat. Rev. Mol. Cell Biol. 2003, 4, $397-407$. [CrossRef]

52. Usatyuk, P.V.; He, D.; Bindokas, V.; Gorshkova, I.A.; Berdyshev, E.V.; Garcia, J.G.N.; Natarajan, V. Photolysis of caged sphingosine1-phosphate induces barrier enhancement and intracellular activation of lung endothelial cell signaling pathways. Am. J. Physiol. Cell. Mol. Physiol. 2011, 300, L840-L850. [CrossRef] [PubMed]

53. Osgood, D.; Miller, M.C.; Messier, A.A.; Gonzalez, L.; Silverberg, G.D. Aging alters mRNA expression of amyloid transporter genes at the blood-brain barrier. Neurobiol. Aging 2017, 57, 178-185. [CrossRef] [PubMed]

54. Toornvliet, R.; Vanberckel, B.; Luurtsema, G.; Lubberink, M.; Geldof, A.A.; Bosch, T.M.; Oerlemans, R.; Lammertsma, A.A.; Franssen, E.J.; Berckel, B.N. Effect of age on functional P-glycoprotein in the blood-brain barrier measured by use of (R)[11C]verapamil and positron emission tomography. Clin. Pharmacol. Ther. 2006, 79, 540-548. [CrossRef] [PubMed]

55. Bartels, A.L.; Kortekaas, R.; Bart, J.; Willemsen, A.T.; de Klerk, O.L.; de Vries, J.J.; van Oostrom, J.C.; Leenders, K.L. Blood-brain barrier P-glycoprotein function decreases in specific brain regions with aging: A possible role in progressive neurodegeneration. Neurobiol. Aging 2009, 30, 1818-1824. [CrossRef]

56. Billington, S.; Salphati, L.; Hop, C.E.C.A.; Chu, X.; Evers, R.; Burdette, D.; Rowbottom, C.; Lai, Y.; Xiao, G.; Humphreys, W.G.; et al. Interindividual and Regional Variability in Drug Transporter Abundance at the Human Blood-Brain Barrier Measured by Quantitative Targeted Proteomics. Clin. Pharmacol. Ther. 2019, 106, 228-237. [CrossRef]

57. Erdő, F.; Krajcsi, P. Age-Related Functional and Expressional Changes in Efflux Pathways at the Blood-Brain Barrier. Front. Aging Neurosci. 2019, 11, 196. [CrossRef]

58. Guay, S.-P.; Légaré, C.; Houde, A.-A.; Mathieu, P.; Bossé, Y.; Bouchard, L. Acetylsalicylic acid, aging and coronary artery disease are associated with ABCA1 DNA methylation in men. Clin. Epigenet. 2014, 6, 14. [CrossRef]

59. Houde, A.-A.; Guay, S.-P.; Desgagné, V.; Hivert, M.-F.; Baillargeon, J.-P.; St-Pierre, J.; Perron, P.; Gaudet, D.; Brisson, D.; Bouchard, L. Adaptations of placental and cord bloodABCA1 DNA methylation profile to maternal metabolic status. Epigenetics 2013, 8 , 1289-1302. [CrossRef]

60. Liang, Y.; Yang, X.; Ma, L.; Cai, X.; Wang, L.; Yang, C.; Li, G.; Zhang, M.; Sun, W.; Jiang, Y. Homocysteine-mediated cholesterol efflux via ABCA1 and ACAT1 DNA methylation in THP-1 monocyte-derived foam cells. Acta Biochim. Biophys. Sin. 2013, 45, 220-228. [CrossRef]

61. Borenstein, A.R.; Mortimer, J.A. Chapter 10-Family History, Genetics, and Down Syndrome. In Alzheimer's Disease; Borenstein, A.R., Mortimer, J.A., Eds.; Academic Press: San Diego, CA, USA, 2016; pp. 107-120.

62. Takechi, T.; Hirota, T.; Sakai, T.; Maeda, N.; Kobayashi, D.; Ieiri, I. Interindividual Differences in the Expression of ATP-Binding Cassette and Solute Carrier Family Transporters in Human Skin: DNA Methylation Regulates Transcriptional Activity of the Human ABCC3 Gene. Drug Metab. Dispos. 2018, 46, 628-635. [CrossRef]

63. Riches, Z.; Abanda, N.; Collier, A.C. BCRP protein levels do not differ regionally in adult human livers, but decline in the elderly. Chem. Interact. 2015, 242, 203-210. [CrossRef] 